\title{
A cytological study of the $\mathrm{O}_{5}$ chromosomal inversion of Drosophila subobscura (Diptera, Drosophilidae)
}

\author{
Francesc Mestres, Maria Teresa Figueras and Luís Serra \\ Departament de Genètica, Facultat de Biologia, Universitat de Barcelona, Barcelona - Spain.
}

\begin{abstract}
The $\mathrm{O}_{5}$ chromosomal inversion has been a cornerstone for understanding different aspects of the American colonization by Drosophila subobscura. To obtain more information of this evolutionary event it is important to know the pattern of bands of this inversion in detail. Comparing this pattern with that of $D$. melanogaster it is possible to predict which genes are located inside or close to the $\mathrm{O}_{5}$ inversion and use them as genetic markers. In this study, the complete band pattern of the $\mathrm{O}_{5}$ inversion is presented. Furthermore, the most important genes located inside it have been predicted. Finally, a constriction located close to the proximal breakage point of the $\mathrm{O}_{5}$ inversion has been observed many times and its possible genetic significance is discussed.
\end{abstract}

Key words: Drosohila subobscura, chromosomal inversion, colonization, lethal genes.

Received: April 16, 2002; accepted: October 4, 2002

\section{Introduction}

Until 1978, D. subobscura was considered a species with a Palearctic area of distribution. In that year this species was first found in the Chilean locality of Puerto Montt (Brncic et al., 1981), but in 1982 it was also detected in Port Townsend (Washington) (Beckenbach and Prevosti, 1986). The species is now found in Chile from La Serena to Punta Arenas and in many localities of Argentina in the Andes mountain range. In North America the species is spread along the West Coast (Prevosti et al., 1987; 1989). This phenomenon of colonization has been studied at different genetic levels: the chromosomal polymorphism (Prevosti et al., 1985; 1988; 1990), the allozyme polymorphism (Prevosti et al., 1983; Balanyà et al., 1994), the lethal genes (Mestres et al., 1990; 1992; 1995; Solé et al., 2000), the polygenes for quantitative traits (Pegueroles et al., 1995; 1999; Huey et al., 2000), the mtDNA (Latorre et al., 1986; Rozas et al., 1990), the genomic DNA variation (Rozas and Aguadé, 1991) and the effect of inbreeding (Pegueroles et al., 1996).

From the beginning our research group tried to search for the origin of the colonization. The chromosomal polymorphism obtained in the American populations of $D$. subobscura (Prevosti et al., 1985; 1988; 1990) showed a high similarity with that from the Western Mediterranean

Send correspondence to Francesc Mestres, Departament de Genètica, Facultat de Biologia, Universitat de Barcelona, Phone: $34-$ 93-4021499, Fax: 34-93-4110969. E-mail: francm@porthos.bio. ub.es. area (Prevosti et al., 1984) with the important exception of the $\mathrm{O}_{5}$ inversion. This inversion is present in the American populations but it has never been found in the Western Mediterranean samples. The $\mathrm{O}_{5}$ inversion from America has an interesting property, it is always completely associated with a lethal gene (Mestres et al., 1990; 1992; 1995). In spite of its association with a lethal gene its frequency shows a clinal distribution with latitude in both colonized areas. However, in the Palearctic region the distribution of $\mathrm{O}_{5}$ is rather erratic (Krimbas and Loukas, 1980; Krimbas, 1993; Mestres et al., 1994; Zivanovic and Mestres, 2000) and its frequency is extremely low with the exception of South Scandinavia (Sperlich, 1964; Pinsker and Sperlich, 1981). Furthermore its combination with lethal genes is variable. Thus, an $\mathrm{O}_{5}$ inversion from Gävle (Sweden) was lethal free, while another one from Lilla Edet (also in Sweden) was found to be semilethal (Mestres et al., 1992). O $_{5}$ inversions from Taulé (France) and Zanjic (Yugoslavia), on the other hand, were associated with lethal genes. However, these lethals were neither allelic between each other nor with those from the American populations (Mestres et al., 1992; Zivanovic and Mestres, 2000). The constant association of the lethal effect and the $\mathrm{O}_{5}$ inversion in America can be used as a tracer to detect the local Palearctic population from which the colonization started. It is most probable that a single $\mathrm{O}_{5}$ gene arrangement with the lethal gene was among the chromosome sample of the colonizing flies (Mestres and Serra, 1995). Thus, if an $\mathrm{O}_{5}$ inversion carrying the lethal gene found in America is detected in a Palearctic population, this could be the one from which the 
colonization started. As the lethal genes from Taule and Zanjic are different from those found in America, the origin of the colonization remains still unknown.

The breakage points of the $\mathrm{O}_{5}$ inversions from Europe and America seem to be the same (Mestres et al., 1992; Zivanovic and Mestres, 2000), but the behavior of the $\mathrm{O}_{5}$ arrangement from America and from the Palearctic region is different. In America significant latitudinal clines can be found (Prevosti et al., 1985; 1988; 1990); its frequency is higher than expected from inbreeding experiments (Pegueroles et al., 1996) and a significantly higher segregation can be observed in recombination studies (Mestres et al., 1998). All these results seem to support that the $\mathrm{O}_{5}$ inversion is associated with an heterotic effect in America (Mestres et al., 2001). Although the breakage points of all $\mathrm{O}_{5}$ inversions studied are identical, the possibility of recurrence in this inversion must be taken into account.

For all these reasons the $\mathrm{O}_{5}$ inversion has a key function for understanding the American colonization by $D$. subobscura. The aim of the present study is to obtain more information about the cytology of this inversion. The detailed analysis of the banding pattern of the $\mathrm{O}_{5}$ inversion will allow a comparison with the genetic and karyotypic information available in other species of Drosophila (mainly $D$. melanogaster), and it might be possible to recognize the genes that are located in the inversion or in its neighborhood.

\section{Material and Methods}

All $\mathrm{O}_{5}$ chromosomal lines available carry a lethal gene and no homokariotypic strain $\mathrm{O}_{5} / \mathrm{O}_{5}$ could be established by inbreeding. However, the lethal gene of the $\mathrm{O}_{5}$ chromosomal lines are not allelic in all cases. For instance, as previously mentioned, the lethal gene associated with the American $\mathrm{O}_{5}$ inversion is not allelic with that from Taulé (France). Thus, it is possible to obtain $\mathrm{O}_{5} / \mathrm{O}_{5}$ individuals with $\mathrm{O}$ chromosomes of different origin. For this purpose the T15 (from Taulé) and the G7A (from Gilroy, California), both $\mathrm{O}_{5}$ chromosomal lines with different lethal genes, were crossed. The strategy of these crosses is presented in Figure 1. One $\mathrm{Va} / \mathrm{O}_{5}$ male from Taulé was crossed with $\mathrm{Va} / \mathrm{O}_{5}$ virgin females from Gilroy. The parental individuals are heterokaryotypic balanced over a chromosome $\mathrm{Va}$ (Varicose) from the $\mathrm{Va} / \mathrm{Ba}$ balanced lethal strain (Sperlich et al., 1977). The Varicose chromosome carries the X-ray induced overlapping inversions $\mathrm{O}_{\underline{\mathrm{VII}}+210}$ and the naturally occurring $\mathrm{O}_{3+4}$ region. Among the offspring the karyotypes: $\mathrm{Va} / \mathrm{O}_{5}, \mathrm{O}_{5} / \mathrm{O}_{5}$ and $\mathrm{Va} / \mathrm{Va}$ are expected, but $\mathrm{Va} / \mathrm{Va}$ genotypes die because the $V a$ gene is a recessive lethal. The problem is the time of lethal effect of the $V a$ gene. Since the $V a$ gene of $D$. subobscura shows the same behavior as the Delta gene of $D$. melanogaster, it is generally assumed that they are homologous genes (Krimbas, 1993). In D. melanogaster, the Delta gene is embryonic lethal (Lindsley and Zimm, 1992). However, if the $\mathrm{Va} / \mathrm{Va}$ genotypes can survive the larval stadium, then both homokaryotypes $\left(\mathrm{O}_{5} / \mathrm{O}_{5}\right.$ and $\mathrm{Va} / \mathrm{Va}$ ) might be present in the $\mathrm{F}_{1}$ larval offspring. Certainly, it would be possible to distinguish these genotypes by their pattern of bands, but this would slow down the analysis. To overcome this problem, one possibility is to perform a more complex strategy of crosses preventing the appearance of $\mathrm{Va} / \mathrm{Va}$ individuals (Mestres et al., 1992). Another option is to determine the time of the lethal effect of $V a$ lethal during development. This study can be done cytologically by examining the karyotype of a greater sample of larvae of the $\mathrm{Va} / \mathrm{Ba}$ lethal balanced strain ( $\mathrm{Va} / \mathrm{Va}$ homozygotes are $\mathrm{O}_{3+4} / \mathrm{O}_{3+4}$ in the distal region of the chromosome $\mathrm{O}$, whereas $\bar{B} a / \overline{B a}$ homozygotes are $\mathrm{O}_{\mathrm{st}} / \mathrm{O}_{\mathrm{st}} \mathrm{t}$. When larvae of the $V a / B a$ strain were analyzed all lhomokaryotypic individuals were $\mathrm{O}_{\mathrm{st}} / \mathrm{O}_{\text {st }}$ (Figure 2). This result confirms that the $V a$ gene (as expected by its equivalence with the Delta gene of $D$. melanogaster) is an embryonic lethal, and the $B a$ gene expresses lethal effects after pupation. Thus, in the

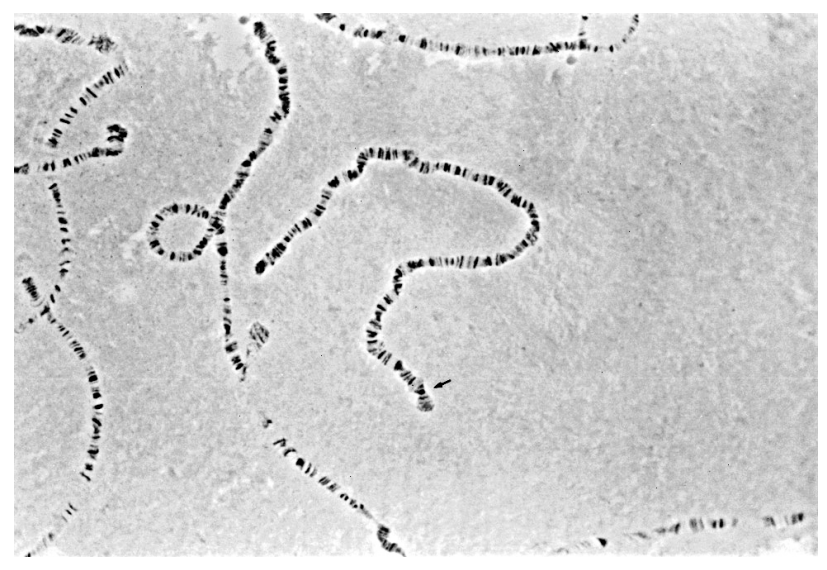

Figure 2 - Homokaryotypes $\mathrm{O}_{\mathrm{st}} / \mathrm{O}_{\mathrm{st}}(B a / B a)$ obtained in the crosses among $\mathrm{Va} / \mathrm{Ba}$ individuals. The arrow indicates the distal tip of the chromosome, where the pattern of bands allows clear differentiation of the $\mathrm{O}_{\text {st }}$ and the $\mathrm{O}_{\underline{3+4}}$ chromosomal arrangements. 400X.

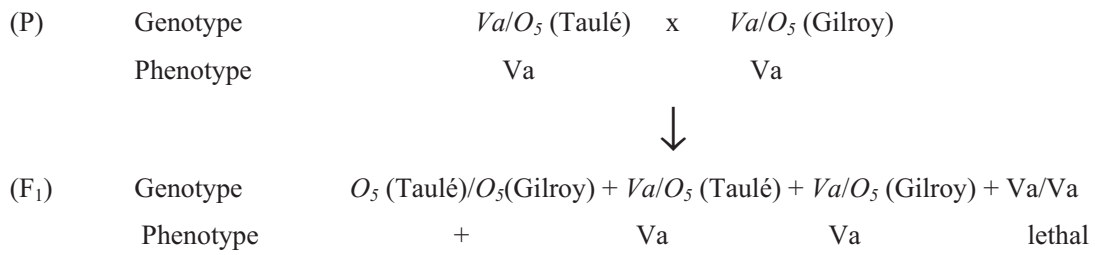

Figure 1 - Crosses performed in order to obtain the homokaryotypes $\mathrm{O}_{5} / \mathrm{O}_{5}$. 
crosses between the lethal chromosomal lines T15 and G7A all homokaryotypes must be $\mathrm{O}_{5} / \mathrm{O}_{5}$.

The polytene chromosomes were stained and squashed in aceto-orcein solution and observed using a light microscope.

\section{Results and Discussion}

The pattern of bands in the $\mathrm{O}_{5} / \mathrm{O}_{5}$ homokaryotypes is presented in Figure 3. The pairing is accurate indicating the full coincidence of the breakage points confirming previous observations (Mestres et al., 1992; Zivanovic and Mestres, 2000). Although it is not possible to exclude a recurrent origin of new $\mathrm{O}_{5}$ inversions by mutation, the probability of this phenomenon is expected to be very low. Using the method proposed by Sperlich and Pfriem (1986) the estimate of this recurrence would be between $1.368 \times 10^{-7}$ and $9.488 \times 10^{-8}$ (Mestres and Serra, 1995) assuming that the breakage points are randomly distributed along the $\mathrm{O}$ chromosome of D. subobscura. However, this is most unlikely, because many "hot spots" can be identified in this chromosome (Kunze-Mühl and Müller, 1958; Krimbas, 1993). The proximal breakage point is mapped in the $83 \mathrm{~B}-\mathrm{C}$ section and very close to the "hot spot" located in the $83 \mathrm{C}-84 \mathrm{~A}$ section (where the breakage points of the $\mathrm{O}_{22}, \mathrm{O}_{15}$ and $\mathrm{O}_{9}$
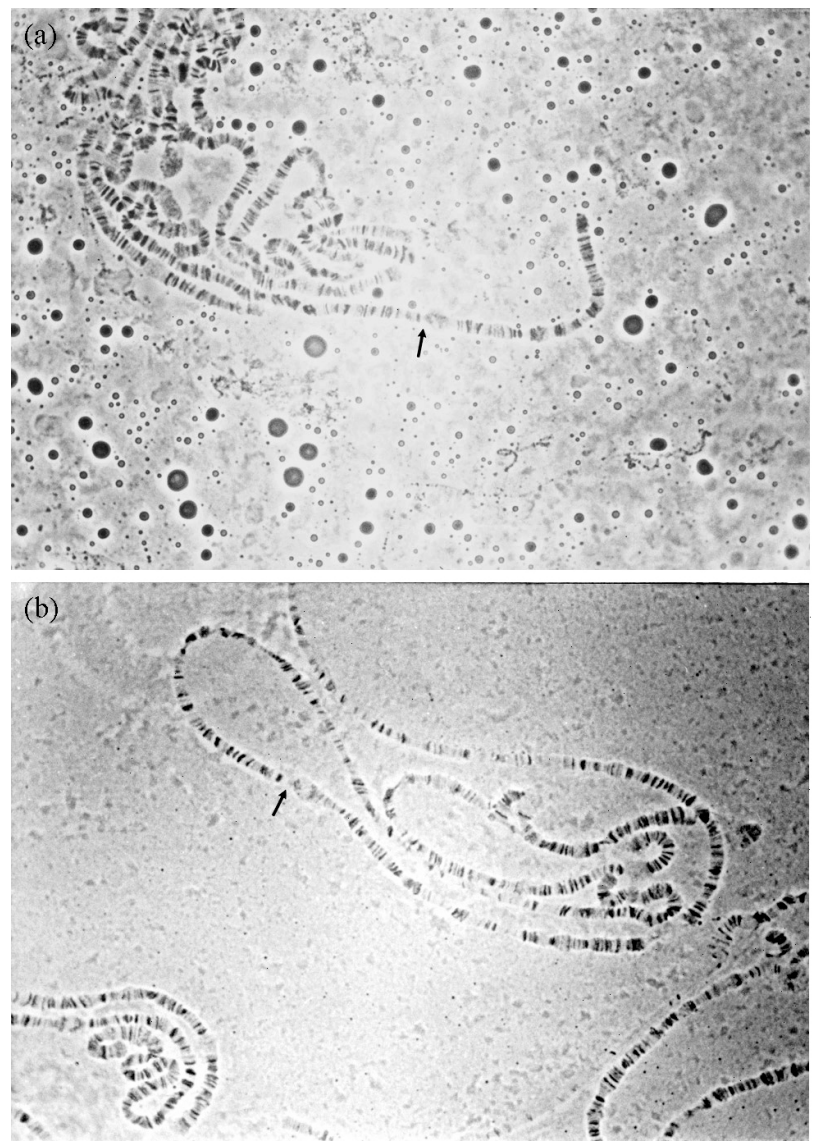

inversions are also located). The distal breakage point is between the $87 \mathrm{D}-87 \mathrm{E}$, not far from the breakage points of the inversions $\mathrm{O}_{12}, \mathrm{O}_{17}$ and $\mathrm{O}_{22}$. Furthermore, in the chromosomes of the homokaryotypes $\mathrm{O}_{5} / \mathrm{O}_{5}$ a constriction was recognized in many cases close to the left breakage points of the $\mathrm{O}_{5}$ inversion (Figs. $4 \mathrm{a}, 4 \mathrm{~b}, 4 \mathrm{c}$ and $4 \mathrm{~d}$ ). This constriction could be related in some way to a "hot spot" of the $\mathrm{O}$

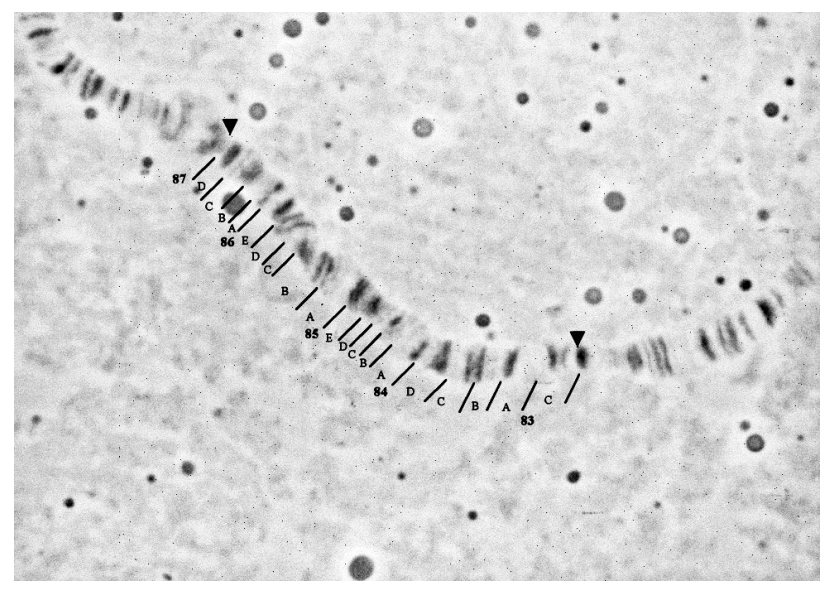

Figure 3 - Pattern of bands of the $\mathrm{O}_{5}$ chromosomal inversion in the homokaryotypes $\mathrm{O}_{5} / \mathrm{O}_{5}$. 1000X. Arrows indicate the breakage points of the inversion.

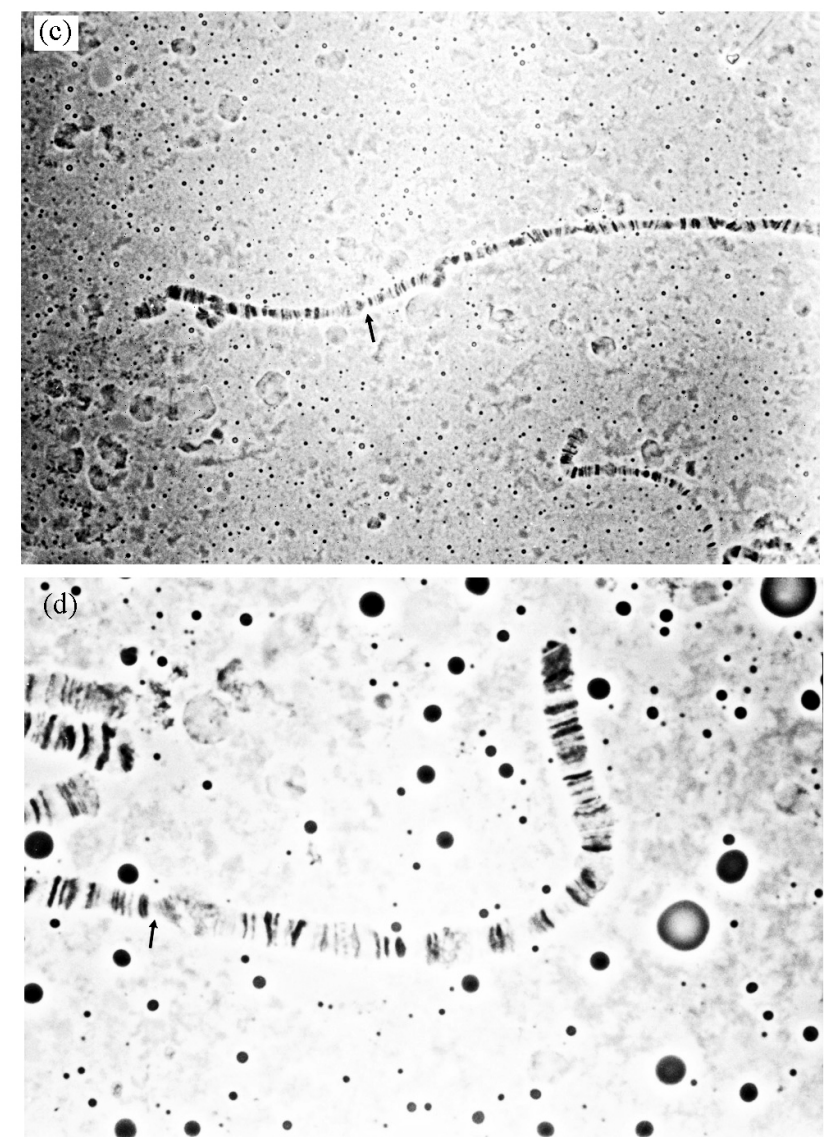

Figure 4 - Different pictures where the constriction located near the $\mathrm{O}_{5}$ inversion proximal breakage point (indicated by an arrow) is presented. (a, b and c) $400 X$. (d) $1000 X$. 
chromosomes of $D$. subobscura where breaks occur more frequently than in other regions and might be discussed in the context of a possible recurrence of the $\mathrm{O}_{5}$ inversion.

As the pattern of bands obtained in the homokaryotype $\mathrm{O}_{5} / \mathrm{O}_{5}$ is very clear, it could be directly compared with that of the $3 \mathrm{R}$ - chromosome arm of D. melanogaster . The region covered by the $\mathrm{O}_{5}$ inversion corresponds approximately to the section 86 - A to 89 - F of the $3 R$ chromosome of D. melanogaster. According to Lindsley and Zimm (1992) the most important genes located in this segment are: Odh (Octanol dehydrogenase), Sdh-2 (Sorbitol dehydrogenase), ants (antennas), cu (curled), man (mandarin), Hsp $70 \mathrm{~A}$ (Heat - shock protein), ttr (tetrapter), ry (rosy), Ace (acetyl cholinesterase), aur (aurora), red (red Malpighian tubes), trx (trithorax), cv-c (crossveinless c), Tm1 (Tropomyosin 1), jvl (javelinlike), Po (Pyridoxal oxidase), Sb (Stubble), ss (spineless), Ubx (Ultrabithorax), abd-A (abdominal A), Abd-B (Abdominal B) and cal (coal). Thus, some of these genes could be used as molecular markers for the $\mathrm{O}_{5}$ inversions from American and Palearctic populations. The DNA of the Odh (86 - D 1-4) and the $S d h-2(86-\mathrm{D})$ genes has been sequenced in $D$. melanogaster (Luque et al., 1994; Luque et al., 1998). Both genes are located inside, but close to the proximal breakage point of the $\mathrm{O}_{5}$ inversion in $D$. subobscura. The DNA sequence of a fragment of the Odh gene of D. subobscura has been recently used to characterize the $\mathrm{O}_{5}$ and other inversions in American and Palearctic populations of $D$. subobscura (Abad, 2000). Homeotic genes such as trx (88 B3), $U b x$ (89 - E1), $a b d-A$ (89 - E2) and $A d b-B$ (89 - E2) have been also characterized at the molecular level in $D$. melanogaster (Martin et al., 1995). These genes map inside and close to the distal breakage point of the $\mathrm{O}_{5}$ inversion, thus it might become possible to cover the two ends of this inversion and use them for future investigations.

\section{Acknowledgements}

This work was supported by grants PB96-0793C04-03 from the Dirección General de Enseñanza Superior (Spain), BOS2000-0295-C02-02 from de Dirección General de Investigación (Spain) and 2000SGR 00068 and 2001SGR 00207 from the Generalitat de Catalunya (Spain).

\section{References}

Abad, L (2000) Utilización del gen octanol deshidrogenasa (Odh) como marcador molecular para el análisis de poblaciones de D. subobscura. Master Dissertation, Universitat de Barcelona, Barcelona.

Balanyà J, Segarra C, Prevosti A and Serra L (1994) Colonization of America by D. subobscura: The founder event and a rapid expansion. J of Hered 85:427-432.

Beckenbach AT and Prevosti A (1986) Colonization of North America by the European species D. subobscura and $D$. ambigua. Am Midl Nat 115:10-18.
Brncic D, Prevosti A, Budnik M, Monclús M and Ocaña J (1981) Colonization of D. subobscura in Chile. I. First population and cytogenetic studies. Genetica 56:3-9.

Huey RB, Gilchrist GW, Carlson ML, Berrigan D and Serra L (2000) Rapid evolution of a geographic cline in size in an introduced fly. Science 287:308-309.

Krimbas CB (1993) D. suboscura: Biology, Genetics and Inversion Polymorphism. Verlag Dr. Kovac, Hamburg.

Krimbas CB and Loukas M (1980) The inversion polymorphism of D. subobscura. Evol Biol 12:163-234.

Kunze-Mühl E und Müller E (1958) Weitere Untersuchungen über die chromosomale Struktur und natürlichen Strukturtypen von D. subobscura. Chromosoma 9:559-570.

Latorre A, Moya A and Ayala FJ (1986) Evolution of mitochondrial DNA in D. subobscura. Proc Natl Acad Sci USA 83:8649-8653.

Lindsley DL and Zimm GG (1992) The genome of $D$. melanogaster. Academic Press Inc., San Diego, USA.

Luque T, Atrian S, Danielsson O, Jörnvall H and GonzàlezDuarte R (1994) Structure of the D. melanogaster glutathione-depemdent formaldehide deydrogenase/octanol dehydrogenase gene (class III alcohol dehydrogenase). Eur J Biochem 225:985-993.

Luque T, Hjelmqvist L, Marfany G, Danielsson O, El-Ahmad M, Persson B, Jörnvall H and Gonzàlez-Duarte R (1998) Sorbitol dehydrogenase of Drosophila. Gene, protein, and expression data show a two-gene system. The J Biol Chem 237:34293-34301.

Martin CH, Mayeda CA, Davis CA, Ericsson CL, Knafels JD, Mathog DR, Celniker SE, Lewis EB and Palazzolo MJ (1995) Complete sequence of the bithorax complex of Drosophila. Proc Natl Acad Sci USA 92:8398-83402.

Mestres F and Serra L (1995) On the origin of the $\mathrm{O}_{5}$ chromosomal inversion in American populations of D. subobscura. Hereditas 123:39-46.

Mestres F, Sanz J and Serra L (1998) Chromosomal structure and recombination between inversions in D. subobscura. Hereditas 128:105-113.

Mestres F, Serra L and Ayala FJ (1995) Colonization of the Americas by D. subobscura: Lethal - gene allelism and association with chromosomal arrangements. Genetics 140:1297-1305.

Mestres F, Pegueroles G, Prevosti A and Serra L (1990) Colonization of America by D. subobscura: Lethal genes and the problem of the $\mathrm{O}_{5}$ inversion. Evolution 44:1823-1836.

Mestres F, Balanyà J, Arenas C, Solé E and Serra L (2001) Colonization of America by D. subobscura: Heterotic effect of chromosomal arrangements revealed by the persistence of lethal genes. Proc Natl Acad Sci USA 98:9167-9170.

Mestres F, Balañà J, Segarra C, Prevosti A and Serra L (1992) Colonization of America by D. subobscura: Analysis of the $\mathrm{O}_{5}$ inversions from Europe and America and their implications for the colonizing process. Evolution 46:1564-1568.

Mestres F, Balañà J, Segarra C, Prevosti A and Serra L (1994) O chromosome inversion polymorphism in Northern and Atlantic Europe and its implications in the American colonization by $D$. subobscura. Z zool Syst Evolut - forsch 32:108-116.

Pegueroles G, Mestres F and Serra L (1996) Analysis of inbreeding in a colonizing population of D. subobscura. Genetica 98:289-296. 
Pegueroles G, Mestres F, Argemí M and Serra L (1999) Phenotypic plasticity in colonizing populations of $D$. subobscura. Genetics and Mol Biol 22:511-516.

Pegueroles G, Papaceit M, Quintana A Guillén A, Prevosti A and Serra L (1995) An experimental study of evolution in progress: clines for quantitative traits in colonizing and Palearctic populations of D. subobscura. Evol Ecol 9:453-465.

Pinsker W and Sperlich D (1981) Geographical pattern of allozyme and inversion polymorphism on chromosome $\mathrm{O}$ of D. subobscura and its evolutionary origin. Genetica 57:5164.

Prevosti A, De Frutos R, Alonso G, Latorre A, Monclús M and Martinez MJ (1984) Genetic differentiation between natural populations of $D$. subobscura in the Western Mediterranean area with respect to chromosomal variation. Génét Sél Evol 16:143-156.

Prevosti A, García MP, Serra L, Aguadé M, Ribó G and Sagarra E (1983) Association between allelic isozyme alleles and chromosomal arrangements in European populations and Chilean colonizers of $D$. subobscura. Isozymes 10:171-191.

Prevosti A, Serra L, Segarra C, Aguadé M, Ribó G and Monclús M (1990) Clines of chromosomal arrangements of $D$. subobscura in South America evolve closer to Old World patterns. Evolution 44:218-221.

Prevosti A, Ribó G, Serra L, Aguadé M, Balañà J, Monclús M and Mestres F (1988) Colonization of America by $D$. subobscura: Experiment in natural populations that supports the adaptive role of chromosomal - inversion polymorphism. Proc Natl Acad Sci USA 85:5597-5600.

Prevosti A, Serra L, Aguadé M, Ribó G, Mestres F, Balañà J and Monclús M (1989) Colonization and Establishment of the Palearctic species D. subobscura in North and South Amer- ica. In: Fontdevila A (ed) Evolutionary Biology of Transient Unstable Populations. Springer Verlag, Berlin, pp 114-129.

Prevosti A, Serra L, Monclús M, Mestres F, Latorre A, Ribó G and Aguadé M (1987) Colonización de América por $D$. subobscura. Evol Biol (Col) 1:1-24.

Prevosti A, Serra L, Ribó G, Aguadé M, Sagarra E, Monclús M and García MP (1985) The colonization of D. subobscura in Chile. II. Clines in the chromosomal arrangements. Evolution 39:838-844.

Rozas J and Aguadé M (1991) Using restriction - map analysis to characterize the colonization process of $D$. subobscura on the American continent. I. rp49 region. Mol Biol Evol 8:447-457.

Rozas J, Hernández M, Cabrera VM and Prevosti A (1990) Colonization of America by D. subobscura: Effect of the founder event on the mitochondrial DNA polymorphism. Mol Biol Evol 7:103-109.

Solé E, Mestres F, Balanyà J, Arenas C and Serra L (2000) Colonization of America by D. subobscura: spatial and temporal lethal-gene allelism. Hereditas 133:65-72.

Sperlich D (1964) Chromosomale Strukturturanalysen und Fertilitatsprunfung an einer marginal Population von $D$. subobscura. Z Vererbungslehere 95:73-81.

Sperlich D and Pfriem P (1986) Chromosomal polymorphism in natural and experimental populations. In: Ashburner $\mathrm{M}$, Carson HL and Thompson Jr, JN (eds) The genetics and Biology of Drosophila. v. 3 ed Academic Press, NY, pp 257309.

Sperlich D, Feuerach-Mravlag H, Lange P, Michaelidis A and Pentzos-Daponte DA (1977) Genetic load and viability distribution in central and marginal populations of $D$. subobscura. Genetics 86:835-848.

Zivanovic $\mathrm{G}$ and Mestres $\mathrm{F}$ (2000) Lethal genes in $\mathrm{O}_{5}$ chromosmes of D. subobscura from Europe and America. J Zool Syst Evol Res 38:123-126. 